\title{
Regulation of alkaline phosphatase synthesis in Phaeocystis sp.
}

\author{
W. H. M. van Boekel ${ }^{1,2}$, M. J. W. Veldhuis ${ }^{2}$ \\ ${ }^{1}$ Department of Marine Biology, University of Groningen, PO Box 14,9750 AA Haren, The Netherlands \\ ${ }^{2}$ Netherlands Institute for Sea Research, PO Box 59, 1790 AB Den Burg, Texel, The Netherlands
}

\begin{abstract}
In short-term experiments, cells of Phaeocystis sp. grown under phosphate-sufficient conditions were harvested and transferred to phosphate-depleted medium. In these cultures alkaline phosphatase activity (APA) developed after a lag-phase of $8 \mathrm{~h}_{\text {; }}$ addition of cycloheximide $\left(10 \mu \mathrm{mol}^{-1}\right)$ partly inhibited APA development. Addition of organic phosphate (AMP, $0.5 \mu \mathrm{mol} \mathrm{l}^{-1}$ ) did not have an inducing effect on alkaline phosphatase synthesis. These results indicate that in Phaeocystis sp. alkaline phosphatase synthesis is controlled by the external phosphate concentration. Synthesis is derepressed at low inorganic phosphate concentration in the medium; the threshold concentration for derepression was ca $0.5 \mu \mathrm{mol} 1^{-1}$ phosphate. The dark synthesis rate of alkaline phosphatase in Phaeocystis sp. was not correlated with the length of the preceding light period for both colony cells and single cells, although at least a $2 \mathrm{~h}$ light period was needed by colony cells to give an enhanced dark synthesis rate compared with a dark control. In a batch culture growth experiment APA developed during the exponential growth phase of Phaeocystis sp. APA development was found to be independent of the initial N/P ratio of the medium. The results imply that APA is not a good indicator of phosphorus limitation in Phaeocystis sp.
\end{abstract}

\section{INTRODUCTION}

Cell-surface phosphatases are enzymes that are associated with freshwater and marine planktonic algae (Kuenzler \& Perras 1965, Healey 1973) and bacteria (Kobori \& Taga 1979). Their function is the release of inorganic phosphate $(\mathrm{Pi}$ ) from organic phosphates that are suspended in the water through hydrolysis of the P-O-C bond (Cembella et al. 1983). Normally, cellsurface phosphatases of unicellular algae have alkaline pH optima (Kuenzler \& Perras 1965) although examples of acid extracellular phosphatases are known (Price 1962, Patni \& Aaronson 1977). There is some controversy concerning the regulation of phosphatase synthesis in unicellular algae (review by Cembella et al. 1983). In some cases algal phosphorus content is found to be the factor controlling phosphatase synthesis (Moller et al. 1975), while in other algae low external phosphate concentrations seem to initiate synthesis (Lien \& Knutsen 1973, Rivkin \& Swift 1980). An inducing effect of dissolved organic phosphates on phosphatase synthesis has been observed as well (Guerrini et al. 1971, Cembella et al. 1984). It is clear that knowledge of the factors controlling alkaline phosphatase synthesis in the dominating algae is necessary for a correct interpretation of alkaline phosphatase activity (APA) data from field situations. Nevertheless, the occurrence of APA in natural systems is often used as an indicator of phosphate limitation in planktonic algae (e.g. Solórzano 1978, Smith \& Kalff 1981, Vincent 1981).

The marine colony-forming flagellate Phaeocystis sp. (Prymnesiophyceae) also produces an alkaline phosphatase (Veldhuis \& Admiraal 1987). During Phaeocystis sp. blooms in the Southern Bight of the North Sea, high APA values were measured when inorganic phosphate concentrations in the water were low (Veldhuis et al. 1987). Because ambient N/P ratios were high, these observations suggest a P-deficiency of the Phaeocystis sp. population. In order to be able to decide whether or not APA is a parameter indicative of P-deficiency in Phaeocystis sp., some factors controlling alkaline phosphatase activity in Phaeocystis sp. were examined.

\section{MATERIAL AND METHODS}

Algal strain. Phaeocystis sp. was isolated from the Southern Bight of the North Sea. This strain was identified as Phaeocystis pouchetii by Veldhuis \& Admiraal 
(1987) but in accordance with Sournia (1988) we will refer to it as Phaeocystis sp. or simply Phaeocystis until the taxonomic problems concerning this genus are solved.

Culturing conditions. Phaeocystis sp. was cultured uni-algal but not axenic in the medium described by Veldhuis \& Admiraal (1987). In this medium $\mathrm{NH}_{4} \mathrm{Cl}$ was omitted so nitrate was the only nitrogen source. Phaeocystis cultures were incubated in serum bottles placed on a rolling device $(3 \mathrm{rpm})$ and illuminated by cool-white fluorescent tubes (Philips no. 34 ; light intensity $115 \mu \mathrm{E} \mathrm{m}^{-2} \mathrm{~s}^{-1}$ ) in a $14 \mathrm{~h}$ light: $10 \mathrm{~h}$ dark cycle at $11^{\circ} \mathrm{C}$.

Short-term experiments. The regulation of alkaline phosphatase synthesis in $\mathrm{Pi}$-sufficient Phaeocystis cells was examined in short-term experiments (Table 1, Expts 1, 3 and 4). The role of external phosphate concentration and of light availability in the regulating process received special emphasis. In preparation of these experiments Phaeocystis was precultured in $3 \mathrm{l}$ serum bottles in medium with initial nitrate and phosphate concentrations of 150 and $5 \mu \mathrm{mol} \mathrm{l}^{-1}$, respectively (Pi-sufficient cultures). These cultures were harvested during the exponential growth phase when Phaeocystis cell numbers were 50 to $100 \times 10^{6} 1^{-1}$, nitrate concentration was $\pm 100 \mu \mathrm{mol} \mathrm{I}^{-1}$ and phosphate concentration was still more than $2 \mu \mathrm{mol} \mathrm{l}^{-1}$. Harvesting (see Fig. 1) of Phaeocystis colonies was done by filtering the culture carefully through $50 \mu \mathrm{m}$ mesh size netting, by which most colonies (and a small part of the single cells) were retained. In Expt 4, to obtain pure colonies, the filtering was repeated twice to remove all single cells. In this experiment single cells of Phaeocystis were harvested from a second Pi-sufficient culture by centrifugation ( $1 \mathrm{~min}, 1000 \times g)$ after filtration of the culture through a $20 \mu \mathrm{m}$ mesh size netting to remove all colonies. After centrifugation, pellets containing single cells only were resuspended in fresh medium. In all short-term experiments harvested cells were transferred to 31 fresh medium, containing 100 umol $1^{-1}$ nitrate but no phosphate. After transfer the phosphate concentration in the new cultures was always less than $0.15 \mathrm{\mu mol}^{-1}$ and cell number was 10 to $50 \times 10^{6} 1^{-1}$ (Pi-depleted cultures). Microscopic examination of colonies and single cells showed that transferring caused no damage. Transfer from Pi-sufficient to Pi-depleted medium was completed within $3 \mathrm{~h}$ after the start of the light period in Expts 1 and 3 and before the end of the dark period in Expt 4. Before use in a short-term experiment the $3 \mathrm{l} \mathrm{Pi}$-depleted cultures were divided into 4 to 12 subcultures that were treated in different ways (see Table 1). The subcultures were incubated in serum bottles under the same conditions as the precultures and the development of alkaline phosphatase activity with time was followed. At the start and end of each experiment samples were taken for Phaeocystis and bacterial cell counts and for nutrient analysis.

Where indicated cycloheximide was added to subcultures from a $1 \mathrm{mmol} \mathrm{l}^{-1}$ stock solution. Cycloheximide is a competitive inhibitor of protein synthesis in eukaryotic organisms (Sisler \& Siegel 1967). This means that the extent of protein synthesis inhibition depends on the cycloheximide concentration. Based on literature references (McMahon 1975, Aaronson \& Patni 1978) we used a $10 \mu \mathrm{mol} \mathrm{l}^{-1}$ cycloheximide concentration in Expt 1. Comparison of APA development in cycloheximide treated subcultures with control subcultures that contained bacteria only (obtained by filtering an identical subculture through Whatman GF/C glass-fiber filter) indicated that a concentration of 25 umol $\mathrm{I}^{-1}$ cycloheximide inhibits alkaline phosphatase

Table 1. Manipulation of subcultures in experiments. Subcultures in Expts 1 to 3 contained both colonies and single cells of Phaeocystis. Subcultures in Expt 4 contained colonies or single cells. Cont. = continuous

Expt 1 Derepression of alkaline phosphatase

Subculture:

Addition:

1

2

$10 \mu \mathrm{M}$ cycloheximide

$0.5 \mu \mathrm{M}$ AMP

4

Expt 2. Relation between N/P ratio and APA development in batch cultures Subculture N/F ratio 1 7.6 2 3

Expt 3. Relation between external inorganic phosphate (Pi) concentration and APA development in algae and bacteria

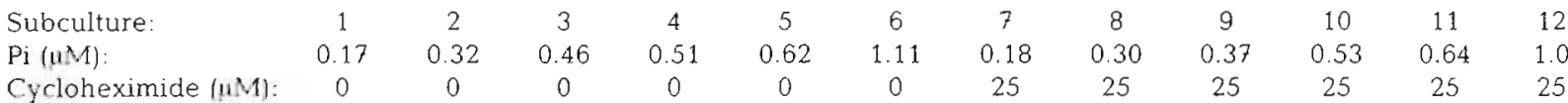

Expt 4. Relation between lightperiod (h) and APA development in colonies and single cells

\begin{tabular}{|c|c|c|c|c|c|c|c|c|c|c|}
\hline \multirow{3}{*}{$\begin{array}{l}\text { Subculture: } \\
\text { Lightperiod: }\end{array}$} & \multicolumn{6}{|c|}{ Colonies } & \multicolumn{4}{|c|}{ Single cells } \\
\hline & 1 & 2 & 3 & 4 & 5 & 6 & 1 & 2 & 3 & 4 \\
\hline & 0 & 1 & 2 & 5 & 8 & Cont. & 0 & 5 & 8 & Cont \\
\hline
\end{tabular}




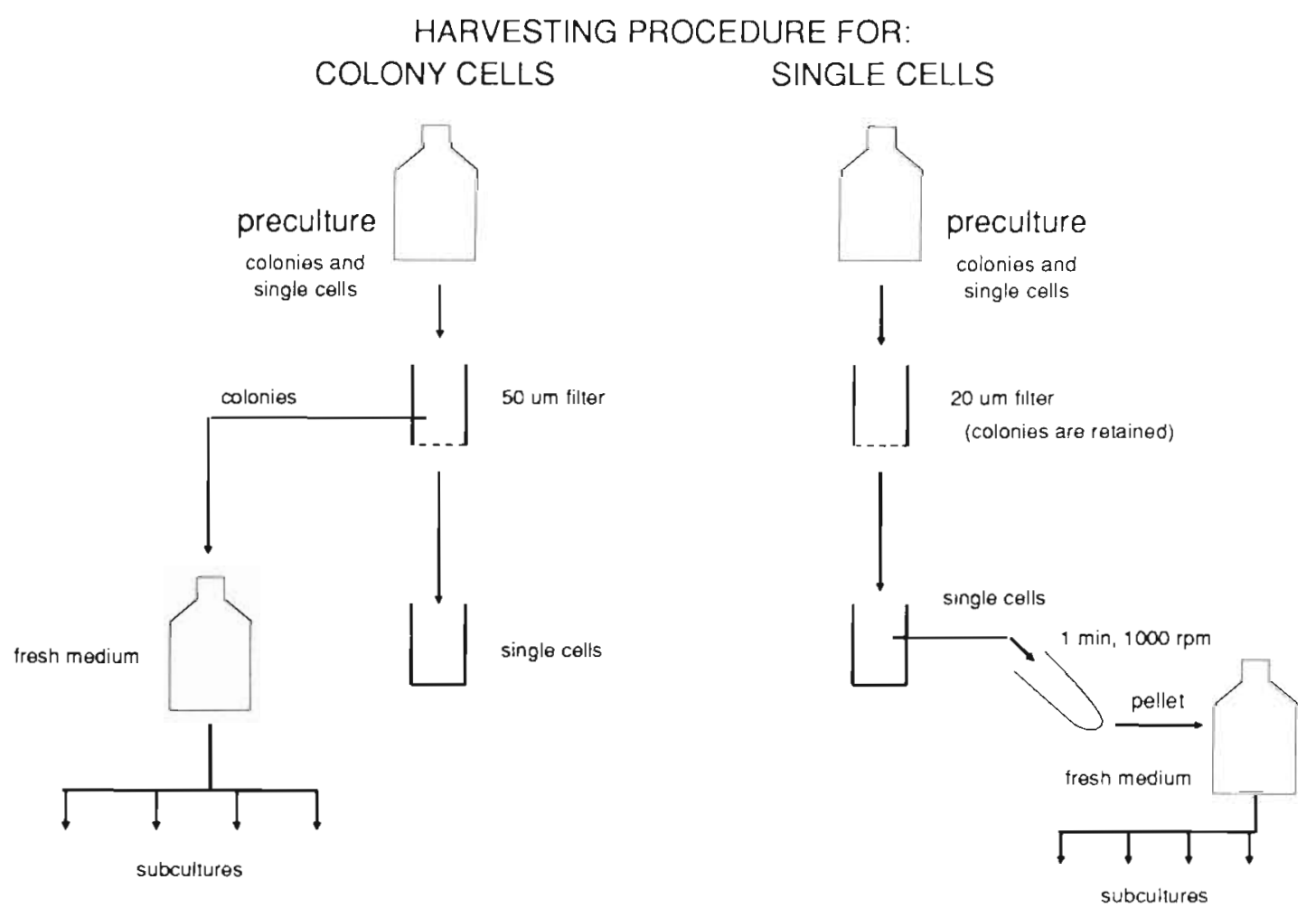

Fig. 1. Phaeocystis sp. Schematic representation of harvesting procedure for both colonies and single cells. For further explanation see text

synthesis in Phaeocystis completely but a cycloheximide concentration of $10 \mu \mathrm{mol}]^{-1}$ does not. Therefore, $25 \mu \mathrm{mol} \mathrm{l}^{-1}$ cycloheximide was added to subcultures in Expt 3 .

In Expt $10.5 \mu \mathrm{mol} \mathrm{l}^{-1}$ AMP was added to a subculture from a $1 \mathrm{mmol} \mathrm{l}^{-1}$ stock solution. AMP is a substrate for the alkaline phosphatase enzyme of Phaeocystis (Admiraal \& Veldhuis 1987). In Expts 1 and 3 inorganic phosphate was added from a $2 \mathrm{mmol} \mathrm{I}^{-1}$ stock solution. All stock solutions were made with double distilled water. In Expt 4 where the influence of different light periods on APA development was examined subcultures were excluded from light by wrapping the bottles in aluminum foil.

Batch culture experiment. The relation between initial N/P ratio in the medium and APA development in Phaeocystis was studied in a batch culture experiment (Expt 2 in Table 1). Phaeocystis was grown in three 11 serum bottles in medium with fixed initial phosphate concentration (ca $2.5 \mathrm{umol} \mathrm{l}^{-1}$ ) but with different initial $\mathrm{N} / \mathrm{P}$ ratio $(7.6,13.1$, and 19.1$)$ in each bottle. Culture conditions were as described above and samples for nutrient analysis, cell counts and APA measurement were taken from each culture at regular intervals.

Biological and chemical analysis. Phaeocystis cells were counted by the Utermöhl sedimentation techni- que (Utermöhl 1958) after fixation of samples with buffered Lugol solution. Single cells and colony cells were counted separately. Bacterial cell counts were done by fluorescence microscopy after fixation of samples with $4 \%$ formalin and staining with DAPI (diamidinopherylindole). Protein was measured according to Lowry et al. (1951). Nitrate concentration was determined with an auto-analyzer according to Strickland \& Parsons (1972), inorganic phosphate concentration following Murphy \& Riley (1962) and cellular phosphorus concentration as inorganic phosphate after persulfate oxidation $\left(1 \mathrm{~h}\right.$ at $\left.120^{\circ} \mathrm{C}\right)$ of pellets. APA was measured fluorimetrically using 3-o-methylfluorescein phosphate (MFP) as substrate (Perry 1972). For most experiments APA is expressed per $10^{6}$ Phaeocystis cells. In these cases APA values were corrected for changes in cell number during the experiment. Bacterial contribution to culture APA was deter-

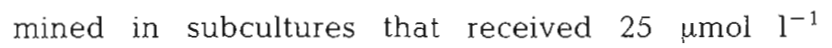
cycloheximide to inhibit algal APA development, or in the filtrates of samples filtered over (Whatman GF/C) glass-fiber filters taken from subcultures. In the latter case bacterial cells were counted in filtrate and subculture in order to compensate for filtration losses of bacteria. Free APA (the APA fraction passing a $0.2 \mu \mathrm{m}$ filter) was never found in the cultures. 


\section{RESULTS}

\section{Experiment 1}

A Pi-sufficient culture of Phaeocystis was transferred to Pi-depleted medium and divided into 4 subcultures (Table 1). At that moment the phosphorus content of the cells in the subcultures was $0.041 \mathrm{pmol}^{-1} \mathrm{ll}^{-1}$. One subculture received no further additions and here APA developed after a lag-phase of ca $8 \mathrm{~h}$ (Fig. 2). APA increased linearly in time over the next $14 \mathrm{~h}$. Addition of cycloheximide $\left(10 \mu \mathrm{mol} \mathrm{l}^{-1}\right)$ to a subculture at the start of the experiment extended the lag phase to ca $12 \mathrm{~h}$ and the following increase in APA with time was much slower. Addition of AMP to a subculture had no effect on the lag phase but the APA developed poorly. In the control (Pi-sufficient) subculture no APA developed during the experiment.

\section{Experiment 2}

In 3 batch cultures of Phaeocystis with the same initial phosphate concentration but with different initial molar N/P ratios (7.6, 13.1, and 19.1, respectively) APA developed as the phosphate concentration in the medium fell below $0.5 \mu \mathrm{mol} \mathrm{l}^{-1}$ (Fig. 3). At that moment the cells were still in the exponential growth phase and the cellular phosphorus content was $>0.06 \mathrm{pmol} \mathrm{cell}^{-1}$. In the stationary phase of P-limited batch cultures the minimal phosphorus content of our Phaeocystis strain was found to be $0.01 \mathrm{pmol} \mathrm{cell}{ }^{-1}$ (results not shown). The Phaeocystis cells in the cultures of Expt 2 were therefore clearly not phosphorus limited as APA developed. Bacterial contribution to APA was not significant in the batch cultures.

\section{Experiment 3}

The role of external phosphate concentration in APA development was further investigated during another short-term experiment. A Pi-sufficient culture of Phaeocystis sp. (cellular phosphorus content $0.025 \mathrm{pmol}$ cell ${ }^{-1}$ ) was harvested and transferred to Pi-free medium. This culture was then divided over 12 serum bottles to which different amounts of phosphate stock solution were added (final concentration 0.17 to $1.11 \mu \mathrm{mol} \mathrm{l}^{-1}$ ). To 6 bottles cycloheximide was added (final concentration $25 \mathrm{umol} \mathrm{l}^{-1}$ ) to determine bacterial APA (Table 1). After $24 \mathrm{~h}$ the APA in all bottles was measured in duplicate. Phaeocystis APA in the subcultures without cycloheximide was determined by subtracting bacterial APA from total APA. In Fig. 4 the relation is shown between the initial phosphate concentration in the medium and the APA after $24 \mathrm{~h}$ for both bacteria and Phaeocystis cells.

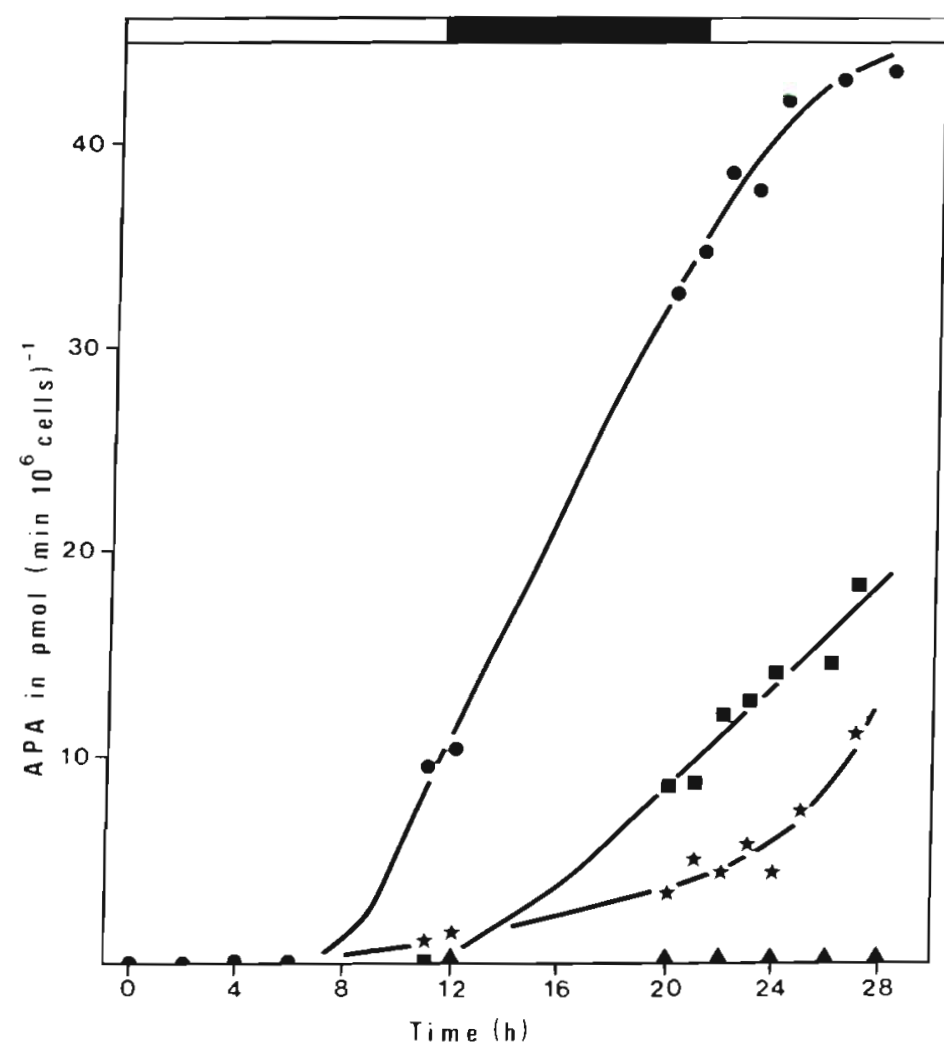

Fig. 2. Phaeocystis sp. Derepression of alkaline phosphatase in subcultures after transfer from Pisufficient to Pi-depleted medium at $\mathrm{t}=0$. Subcultures contamed $35 \%$ colony cells. Bar at top of figure indicates dark period. Curves are: (•) Pidepleted medium, $\left[\mathrm{PO}_{4}\right]<0.1 \mu \mathrm{M}$ at $\mathrm{t}=0_{i}$ (-) $\mathrm{Pi}$ depleted medium, 10 wM cycloheximide added at $t$ $=0 ;(\star)$ Pi-depleted medium, 0.5 $\mu$ M AMP added at $\mathrm{t}=0_{i}(\mathbf{\Lambda})$ Pi-sufficient medium, $8.0 \mu \mathrm{M} \mathrm{PO}_{4}$ added at 
Fig. 3. Phaeocystis sp. Total cell number, percentage colony cells, nitrate and phosphate concentrations and alkaline phosphatase activity (APA) in 3 batch cultures with different initial molar N/P ratio (indicated in upper corner of each figure)
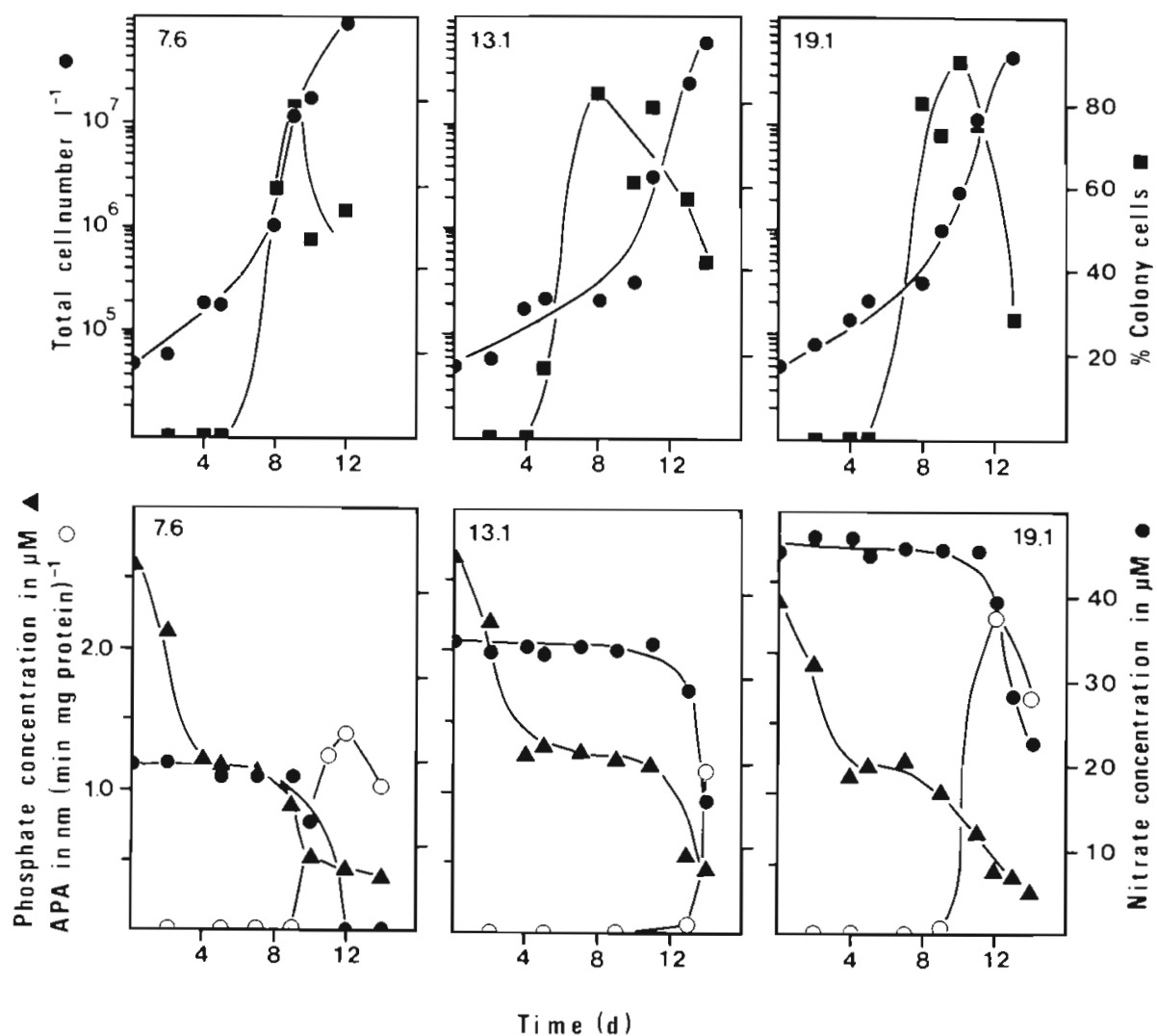

Apparently, a threshold concentration of phosphate in the medium existed below which alkaline phosphatase synthesis was derepressed. The value of this threshold concentration could only be estimated because the phosphate concentration in the medium was not kept at a constant level during the experiment. The value lies

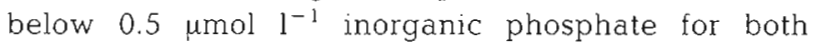
phaeocystis cells and bacteria.

\section{Experiment 4}

In order to investigate the influence of light on APA development, Pi-depleted subcultures containing either colony cells or single cells of Phaeocystis were exposed to light for different periods (Table 1). The cell types were harvested separately from different Pi-sufficient cultures. Harvesting $(t=0)$ was done at the end of the $10 \mathrm{~h}$ dark period so the energy reserves of the cells were low, but probably not depleted. The bacterial contribution to subculture APA was determined at the end of the experiment. The results of this experiment (Fig. 5) show that a $5 \mathrm{~h}$ light period was sufficient for both colony cells and single cells of Phaeocystis to continue alkaline phosphatase synthesis in the dark at the same rate as in the light. For colony cells a 1 or $2 \mathrm{~h}$ light period did not result in a higher alkaline phos- phatase synthesis rate compared with the dark control. At the end of the experiment, bacterial APA values were ca $60 \%$ and $45 \%$ of total APA in the dark bottle for subcultures of colony cells and single cells, respectively. Values were comparable between the subcultures of each cell type.

\section{DISCUSSION}

The results shown in Figs. 2 to 4 clearly demonstrate that alkaline phosphatase synthesis in Phaeocystis is controlled by the external phosphate concentration. At the moment of harvesting the phosphorus content of Phaeocystis cells was 0.02 to $0.06 \mathrm{pmol} \mathrm{cell} \mathrm{p}^{-1}$. The minimal phosphorus content of $0.01 \mathrm{pmol}^{-1}$ found for our Phaeocystis strain is in close agreement with results of Jahnke (1989) who found a minimal content of 0.008 pmole cell $^{-1}$ in Phaeocystis strains isolated from the southern North Sea. Even when growing at $\mu_{\max }$ $\left(\approx 0.8 \mathrm{~d}^{-1}\right.$ in our experiments $)$, the lag-period of $8 \mathrm{~h}$ would have caused only a $23 \%$ reduction of the internal phosphorus content in Phaeocystis cells in experiments shown in Figs. 2 and 4. Internal P was therefore not limiting at the moment APA development started. The results of the batch culture growth experiment (Fig. 3) support this conclusion since APA development 


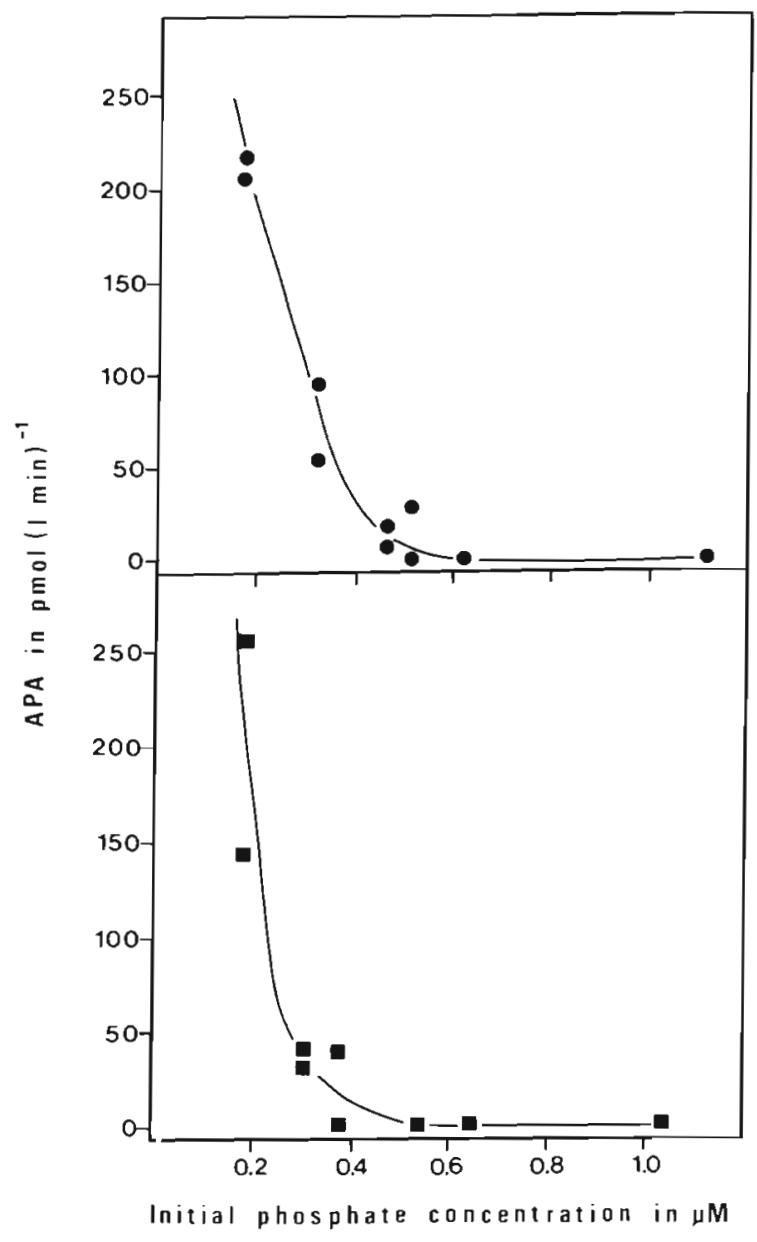

Fig. 4. Influence of phosphate concentration on the development of APA in cells of Phaeocystis sp. and in bacteria. Bacterial APA (-) was measured after $24 \mathrm{~h}$ in cultures that received 25 umol $1^{-1}$ cycloheximide at the start of the experiment. Algal APA $\bullet$ was calculated by substracting bacterial APA from total culture APA

was initiated during the exponential (not-limited) growth phase. Other authors also have found evidence that the external phosphate concentration regulates phosphatase synthesis in algae. Lien \& Knutsen (1973) found an acid phosphatase in Chlamydomonas reinhardti that was derepressed after a lag-phase of $2 \mathrm{~h}$ upon transfer of the algae to Pi-depleted medium. Addition of inorganic phosphate to this culture stopped acid phosphatase synthesis. For a freshwater lake Chróst et al. (1989) found that algal APA development was initiated by the decrease of inorganic phosphate in the water. Taft et al. (1977) concluded the same for a plankton assemblage in a saltwater bay.

Perry (1976) measured low APA in a $\mathrm{N}$-limited chemostat culture of Thalassiosira pseudonana growing at low $\mu$ and a residual phosphate concentration of $0.3 \mu \mathrm{mol} 1^{-1}$ According to Perry this low APA was caused by leakage of the cells due to the low growth rate. In view of our results (Figs. 2 to 4 ) it can be suggested that the APA of $T$ pseudonana was caused by the low phosphate concentration in the medium even though $\mathrm{N}$ was the limiting factor.

In our batch culture experiment (Fig. 3) APA development showed no relation with initial N/P-ratio in the medium. APA developed in all cultures when the external inorganic phosphate concentration fell below $0.5 \mu \mathrm{mol} 1^{-1}$. It would be tempting to state that in the subculture with initial N/P ratio of 7.6 nitrogen was limiting growth since all nitrate in the medium was consumed. This would mean that APA occurred in Phaeocystis under N-limited conditions. However, in all batch cultures the nitrate concentration showed only a small decrease during the first part of the exponential growth phase and a steep fall during the second part. The amount of nitrate consumed in the early exponential growth phase was insufficient to account for the concomitant increase in Phaeocystis cell number. This might indicate that an internal store of nitrogen in the Phaeocystis cells is used during the early exponential growth phase. If Phaeocystis is indeed able to store nitrogen then $\mathrm{N}$-limitation cannot be predicted from nitrate depletion in the medium. The results of the batch culture experiment, therefore, only show that Phaeocystis developed high APA under P-sufficient conditions.

Veldhuis et al. (1987) found threshold phosphate concentrations of 0.5 and $0.2 \mu_{\mathrm{mol}} \mathrm{l}^{-1}$ for APA development in batch cultures and natural populations of Phaeocystis, respectively. Their results are in agreement with the Pi-APA relation found here (Fig. 4). The lower threshold concentration for natural populations may reflect a different physiological state of the cells, caused by different growth conditions.

The concentration of $10 \mu \mathrm{mol} \mathrm{l}^{-1}$ cycloheximide used in Expt 1 (Fig. 2) was not sufficient for a complete inhibition of protein synthesis in Phaeocystis. In the subculture with cycloheximide the APA originated, therefore, from both bacteria and Phaeocystis cells. In this subculture the lag-phase before APA development was prolonged. Since cycloheximide inhibits all protein synthesis and to some extent other cell processes too (McMahon 1975) the longer lag-phase may be caused by a general inhibition of cell metabolism in the Phaeocystis cells. Also, this result indicates that the lagphase for APA development in the contaminating bacteria is longer than in Phaeocystis. In the cycloheximide treated subculture the rate of APA development was slow compared with the subculture without additions since Phaeocystis contributed only partly in alkaline phosphatase synthesis. These differences between APA development in the subculture without additions and the subculture with added cycloheximide clearly 
Fig. 5. Phaeocystis sp. Development of APA in subcultures in relation to light conditions; differences between colony cells and single cells. Cultures were harvested at the end of a $10 \mathrm{~h}$ dark period $(t=0)$. Subcultures were illuminated for the following periods after $\mathrm{t}=0: 0 \mathrm{~h}$ (४), $1 \mathrm{~h}(0), 2 \mathrm{~h}(\square), 5 \mathrm{~h}(\star), 8 \mathrm{~h}(\bullet)$, and in continuous (a) light, Note different scales on $y$-axis

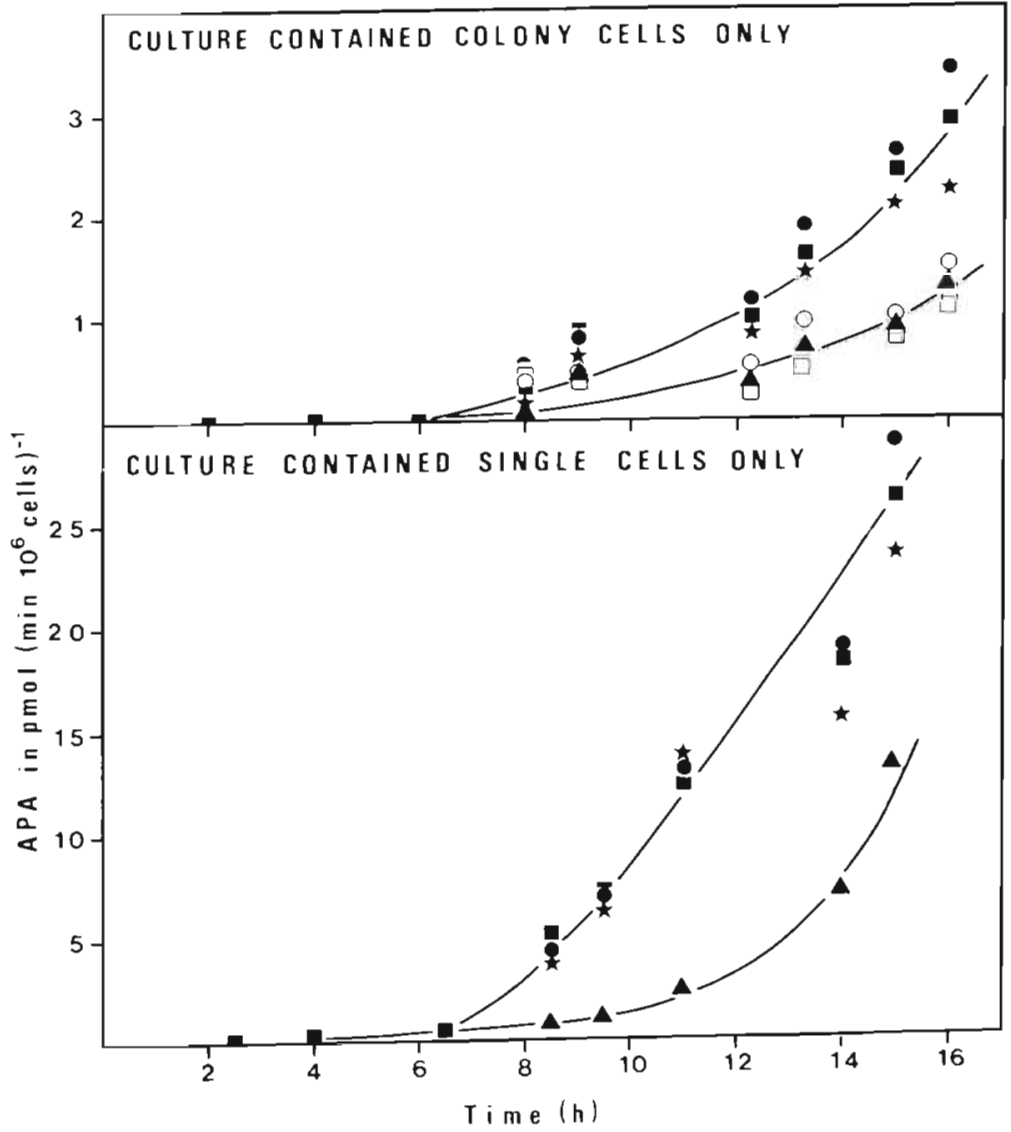

indicate that upon transfer of Phaeocystis cells to Pidepleted medium de novo protein synthesis was required for the development of APA. In other algae alkaline phosphatase is also not constitutive (Kuenzler \& Perras 1965, Cembella et al. 1983).

The presence of $0.5 \mu \mathrm{mol} \mathrm{l^{-1 }}$ AMP did not stimulate alkaline phosphatase synthesis in Phaeocystis (Fig. 2). Instead APA development in the subculture with AMP was slow compared with that without additions. Partly this was caused by the fact that AMP is a competitive inhibitor of the hydrolysis of MFP by alkaline phosphatase. Inorganic phosphate in the medium has the same effect (Pettersson 1979). The true APA that developed in the cultures during the experiments was therefore higher than the measured APA. The concentrations of AMP and inorganic phosphate were not followed with time but the effect of competitive inhibition on APA values was calculated by the use of the inhibition constants of AMP and $\mathrm{Pi}(0.46$ and $1.18 \mu \mathrm{M}$, respectively; preliminary results). The true $A P A$ in the subculture with AMP (Fig. 2) would in the most extreme case (no AMP hydrolysed during the experiment) be 2 times the measured APA, while the low Pi concentrations in the subcultures had no significant influence on the APA values. Taking this into account the APA development in the subculture with AMP was still slow compared with the control. It cannot be excluded though that $\triangle M P$ has a stronger competitive effect on the reaction of bacterial alkaline phosphatase with MFP thereby causing an underestimation of the calculated APA values. Since it is known that bacteria can assimilate organic phosphates (Fenchel \& Blackburn 1979) the difference might also be explained by assuming that bacterial APA development in the subculture with AMP was less as a consequence of the direct uptake of AMP from the medium by the bacteria.

The energy and organic carbon required by Phaeocystis for alkaline phosphatase synthesis (as for protein synthesis in general) originates from photosynthesis in the light and from photosynthetically fixed Creserve material in the dark. Lancelot et al. (1986) found a dependence on 'previous light history' of dark protein synthesis in Phaeocystis colonies. A light period of at least $3 \mathrm{~h}$ was needed by Phaeocystis to allow continued protein synthesis in the following dark period. Above this time threshold the protein synthesis rate in the dark was positively correlated with the length of the preceding light period. In our Expt 4 a $2 \mathrm{~h}$ light period did not enhance the alkaline phosphatase synthesis rate in colonies of Phaeocystis compared with 
the dark control (Fig. 5). A light period of 5 h or more did give an enhanced dark alkaline phosphatase synthesis rate for both colonies and single cells of $P$ haeocystis but there was no positive correlation between synthesis rate and length of the light period as was found by Lancelot et al. (1986). Apparently, after a light period of $5 \mathrm{~h}$ or more energy supply was not limiting in Phaeocystis and the alkaline phosphatase synthesis rate was determined by the external phosphate concentration which was the same in all subcultures. In the experiment shown in Fig. 5, single cells expressed a higher APA compared with colony cells. This is probably caused by a difference in the growth phase of the two cultures at the moment they were harvested.

Alkaline phosphatase synthesis in bacteria contaminating the algal cultures appears to be regulated in the same way as in Phaeocystis (Fig. 4). Production of Pirepressible alkaline phosphatases is known in several bacteria (Torriani 1960, Day \& Ingram 1973, Hassan \& Pratt 1977), but other bacteria have constitutive alkaline phosphatases (Hassan \& Pratt 1977). Selection in the bacterial population of the Phaeocystis cultures may have favoured a few bacterial species. The results therefore, only implicate the fact that one or more marine bacteria have a Pi-repressible alkaline phosphatase.

The presence of APA in natural waters is often regarded as an indicator of P-limitation (e.g. Perry 1972, Chiaudani \& Vighi 1982, Myklestad \& Sakshaug 1983). Our results show that the presence of APA during Phaeocystis blooms only indicates a low external phosphate concentration and does not need to imply P-limitation.

Acknowledgements. This work is a contribution to the EEC research project on the Dynamics of Phaeocystis blooms in nutrient enriched coastal zones [Contract no. EV4V-0102$B(G D F)\}$. The authors wish to thank W. W. C. Gieskes, R. Riegman., J. Stefel.s, C. Lancelot, M. J. Dring, and an anonymous referee for their critical comments on earler drafts of the manuscript. $T$ Keuning is acknowledged for drawing the figures.

\section{LITERATURE CITED}

Aaronson, S., Patni, N. J. (1978). Stimulation of acid phosphatase synthesis and secretion in Ochromonas danica by chloramphenicol base. J. gen. Microbiol. 104: 181-186

Admiraal, W. Veldhuis, M. J. W (1987). Determination of nucleosides and nucleotides in seawater by HPLC: application to phosphatase activity in cultures of the alga Phaeocystis pouchetii. Mar Ecol. Prog. Ser. 36: 277-285

Cembella, A. D. Antia, N. J., Harrison, P. J. (1983). The utilization of inorganic and organic phosphorous compounds as nutrients by eukaryotic microalgae: a multidisciplinary perspective. CRC critical. Rev. Microbiol. 10: 317-391

Chiaudani, G., Vighi, M. (1982). Multistep approach to identification of limiting nutrients in northern Adriatic eutrophied coastal waters. Water Res. 16: 1161-1166
Chróst, R. J., Münster, U., Rai, H., Albrecht, D., Witzel, P. K., Overbeck, J. (1989). Photosynthetic production and exoenzymatic degradation of organic matter in the euphotic zone of a eutrophic lake. J. Plankton Res. 11: 223-24.2

Day, D. F., Ingram, J. M. (1973). Purification and characterization of Pseudomonas aeruginosa alkaline phosphatase. Can. J. Microbiol. 19: 1225-1233

Fenchel, T., Blackburn, T. H. (1979). Bacteria and mineral cycling. Academic Press Inc., London

Guerrini, A. M., Cremona, T., Preddie, E. C. (1971). Influence of $\beta$-glycerophosphate, acetate and $\mathrm{CO}_{2}$ in the appearance of an alkaline phosphatase in Chlamydomonas reinhardii. Biochem. biophys. Res. Commun. 42: 558-563

Hassan, H. M. Pratt, D. (1977). Biochemical and physiological properties of alkaline phosphatases in five isolates of marine bacteria. J. Bacteriol. 129: 1607-1612

Healey, F. P. (1973). Characteristics of phosphorus deficiency in Anabaena. J. Phycol. 9: 383-394

Jahnke, J. (1989). The light and temperature dependence of growth rate and elemental composition of Phaeocystis globosa Scherffel and $P$. pouchetii (Har.) Lagerh. in batch cultures. Neth. J. Sea Res. 23: 15-21

Kobori, H., Taga, N. (1979). Phosphatase activity and its rôle in the mineralization of organic phosphorus in coastal sea water. J. exp. mar. Biol. Ecol. 36: 23-39

Kuenzler, E. J., Perras, J. P. (1965). Phosphatases of marine algae. Biol. Bull. mar. biol. Lab. Woods Hole 138: 271-284

Lancelot, C., Mathot, S., Owens, N. J. P. (1986). Modelling protein synthesis, a step to an accurate estimate of net primary production: Phaeocystis pouchetii colonies in Belgian coastal waters. Mar Ecol. Prog. Ser. 32: 193-202

Lien, T., Knutsen, G. (1973). Synchronous cultures of Chlamydomonas reinhardti: properties and regulation of repressible phosphatases. Physiologia Pl. 28: 291-298

Lowry, P. J., Rosenbrough, N. J., Farr, A. L., Randall, R. J. (1951). Protein measurements with Folin-phenol reagent. J. biol. Chem. 193: 265-275

McMahon, D. (1975). Cycloheximide is not a specific inhibitor of protein synthesis in vivo. Pl. Physiol. 55: 815-821

Moller, M., Myklestad, S., Haug, A. (1975). Alkaline and acid phosphatases of the marine diatoms Chaetoceros affinis var. willei (Gran.) Hustedt and Skeletonema costatum (Grev.) Cleve. J. exp. mar Biol. Ecol. 19: 217-226

Murphy, J., Riley, J. P. (1962). A modified single solution method for the determination of phosphate in natural waters. Analytica chim. Acta 27: 31-36

Myklestad, S., Sakshaug, E. (1983). Alkaline phosphatase activity of Skeletonema populations in the Trondheimsfjord. J. Plankton Res. 5: 557-564

Patni, N. J., Aaronson, S. (1977). Stimulation of acid phosphatase secretion in a lower eukaryote. Ochromonas danica, by specific organic phosphatases. Biochim biophys. Acta 478 : 209-214

Perry, M. J. (1972). Alkaline phosphatase activity in subtropical Central North Pacific water using a sensitive fluorimetnc method Mar Biol. 15: 113-119

Perry, M. J. (1976). Phosphate utilization by an oceanic diatom in phosphorus-limited chemostat culture and in the oligotrophic waters of the central North Pacific. Limnol. Oceanogr. 21: 88-107

Pettersson, K. (1979). Enzymatic determination of orthophosphate in natural waters. Int. Revue ges. Hydrobiol. 64 585-607

Price, C. A. (1962). Repression of acid phosphatase synthesis in Euglena gracilis. Science, N.Y. 135: 46

Rivkin, R. B., Swift, E. (1980). Characterization of alkaline phosphatase and organic phosphorous utilization in the 
oceanic dinoflagellate Pyrocystis noctiluca. Mar Biol. 61. $1-8$

Sisler, H. D., Siegel, M. R. (1967). Cycloheximide and other glutarimide antibiotics. In: Gottlieb, D., Shaw, P. D. (ed.) Antibiotics, Vol. 1. Springer Verlag, Berlin, p. 283-307

Smith, R. E. H., Kalff, J. (1981). The effect of phosphorus limitation on algal growth rates: evidence from alkaline phosphatase. Can. J. Fish. aquat. Sci. 38: 1421-1427

Solórzano, L. (1978). Soluble fractions of phosphorus compounds and alkaline phosphatase activity in loch Crenan and loch Etive, Scotland. J. exp. mar. Biol. Ecol. 34:227-232

Sournia, A. (1988). Phaeocystis (Prymnesiophyceae): how many species? Nova Hedwigia 47: 211-217

Strickland, J. D. H., Parsons, T R. (1972). A practical handbook of seawater analysis. Bull. Fish. Res. Bd Can. 167: 1-310

Taft, J. L., Loftus, M. E., Taylor, W R. (1977). Phosphate uptake from phospho-monoesters by phytoplankton in the Chesapeake Bay. Limnol. Oceanogr 22: 1012-1021

This article was submitted to the editor
Torriani, A. (1960). Influence of inorganic phosphate in the formation of phosphatases by Escherichia coli. Biochim. biophys. Acta 38: 460-469

Utermöhl, H. (1958). Zur Vervollkommnung der quantitativen Phytoplankton-Methodik. Mitt. int. Verein. theor angew. Limnol. 9: 1-38

Veldhuis, M. J. W., Admiraal, W. (1987). The influence of phosphate depletion on the growth and colony formation of Phaeocystis pouchetii (Hariot) Lagerheim. Mar. Biol. 95: $47-54$

Veldhuis, M. J. W., Venekamp, L. A. H., retswaart, T (1987). Availability of phosphorus sources for blooms of Phaeocystis pouchetii (Haptophyceae) in the North Sea: impact of the river Rhine. Neth. J. Sea Res. 21. 219-229

Vincent, W. F. (1981). Rapid physiological assays for nutrient demand by the plankton. II. Phosphorus. J. Plankton Res. 3: $699-710$

Manuscript first received: June 2, 1989

Revised version accepted: January 10, 1990 